\title{
Legal Issues in Implementing E-Commerce in GCC Countries from the Perspective of Financial Managers
}

\author{
Omar Masood ${ }^{1}$, Kiran Javaria ${ }^{2}$ \\ ${ }^{1}$ School of Accountancy and Finance, University of Lahore, Pakistan \\ masood_omar@hotmail.com \\ 2 School of Accountancy and Finance, University of Lahore, Pakistan \\ kiranmaryam23@gmail.com
}

\begin{abstract}
Introduction to The Problem: This study explains the concept of legal risk in marketing in e-commerce world as there is currently insufficient research studies on the concept despite its critical importance in influencing the behaviour of consumers. Purpose/Objective Study: The problem statement/purpose of study is to explain that what are the different barriers faced by financial managers during an uncertain and legal risky situation.

Design/Methodology/Approach: The study utilizes both primary and secondary data from Gulf Cooperation Council (GCC) countries in order to get reliable results. There are different risk factors that affect the purchasing behaviour of consumers who shop online. The consumer's perception of risk may be the result of all the emotional processes through which consumers recognize, organize and provide meaning to sensations received, such as the need for product quality, safety online and overall satisfaction. The primary data consists of a survey of online shoppers. The research data and questionnaire were administered to 972 GCC internet users who are classed as experienced and avid users. The secondary data includes an analysis of the various theories of consumer behaviour, models of online adoption, legal risk factors to marketing and shopping online, models of the adoption of innovation and new ways of marketing and trade. Both techniques are utilized to examine the relationship between perceived risk strategies and customer satisfaction as well as examined the customer involvement and propensity to take risk on existing relation of online shopping.
\end{abstract}

Findings: According to study results, legal risk is very important in GCC countries which ultimately influence the customer involvement, satisfaction and purchasing behaviour. GCC countries should attempts to create a coherent legal and regulatory framework (like Lessons can be learnt from the EU). It will help to reduce the legal risk and remove the obstacles to the growth of e-commerce in GCC countries by affirming a certain level of transparency by imposing prior information requirements for electronic contracts, as well as regulating commercial communication and advertisements and regulating consumers' technical errors.

Paper Type: Research Article 
Keywords: E-Commerce's Legal Issues; Risk Management; Financial Manager; Perceived Risk Strategies; Customer Satisfaction

\section{Introduction}

In today's competitive environment, technology is the most efficient means through which organization communicate, keep themselves in touch with market and gained competitive advantage. E-Commerce shopping or buying through internet is one of the rapid growing phenomenon (Lim, et al, 2016). It is important for the E-retailers to maintain customer repurchase intention and sustain operations in order to gain competitive advantage in the market (Kuo, Hu \& Yang, 2013). In an e-Commerce world it is important for the service provider to engage with customers and provide them security from all the risks faced by online consumers. Researchers said "examined the impact on the adoption of the purchase through the Internet and have outlined them as: financial risk, functional, social and physical environment, incorporating the fifth dimension of this specific sales system, the risk of privacy (Kim \& Hong, 2010; Cunningham, 2005). Contrasts the opposite effect, by detecting a significant effect of dimensions of risk on purchase intention via the Internet but not their attitudes toward such behaviour (Kim, 2005). Based on the work of Gierl in 2003 analysed the effect of six dimensions of perceived risk on the adoption of electronic commerce (Gierl, 2003). In particular, these authors refer to functional components, financial, time, psychological, and social and privacy arguing that the latter replaces the physical risk in electronic environment. The Empirical evidence supports the influence gained in all dimensions, except social intention of adoption of electronic commerce" (Bianchi \& Mathews, 2016).

The main motivation of this research is that it strongly contributes to the lack of available research materials on marketing risk. Despite the quantity of published studies on the subject, including several reviews (Mitchell, 1990; Laroche, 2004), most of research in this area focuses on the perception of risk in relation to categories of products, disregarding the means to purchase and customer satisfaction. This study provides major contribution in e-commerce technology world. The aims of this research are to study the concept of risk in marketing in e-commerce world as there is currently insufficient research studies on the concept despite its critical importance in influencing the behaviour of consumers. The analysis of risk has been a field without boundaries in academia, it has been investigated in areas such medicine, social sciences, among others (Klein; Sterk, 2003). It is stated by many authors that ecommerce shopping is one of the most rapid growing phenomena nowadays (Lim, et al, 2016). This area of knowledge has a great influence on theories of marketing, especially in the analysis of consumer behaviour. The aim of the study is to identify the different theories and dimensions of risks by consumers as they purchase through e-commerce and analyse the efforts of the consumer, through the strategies of reducing the legal risk, in the process of purchase through e-commerce and measure consumer satisfaction in the process of buying. 
The main contribution of this study is to identify the best practice lessons and legal principles in GCC countries for e-commerce businesses. "One of the main objectives of the Gulf Cooperation Council (GCC) is to achieve consistency and harmonization in the legislative frameworks of the Gulf States, especially in the area of ecommerce, which covers local and cross-border sale of goods and services via electronic means. This makes it a particularly interesting legal study for investigating the extent to which developing legislation of electronic contract law and e-commerce can be said to contribute to the level of prosperity and growth of e-commerce within a selected region of GCC countries."

This paper is divided into four parts. $2^{\text {nd }}$ part will give the literature review which explains different types of risk reduction strategies and its impact on customer satisfaction and also supports with theoretical background. $3^{\text {rd }}$ part demonstrates the research methodology of the paper. $4^{\text {th }}$ part will give empirical analysis and $5^{\text {th }}$ part will finally conclude with recommendations.

\section{Methodology}

Present research methodology used quantitative based approach and study utilized triangulation method for data collection. In triangulation method researcher used different data source to validate the results. Data was collected from six Gulf Cooperation Council (GCC) countries includes Bahrain, Kuwait, Oman, Qatar, Saudi Arabia, and the United Arab Emirates. In this study researcher utilized two methods which includes: Primary data collection and Secondary data collection (Theoretical Support). Primary data consist of a survey of online shoppers. The data collection instrument of this phase was a semi-structured script. Questionnaires are administered to a sample segment of the population of consumers who shop online from different online website in selected six countries (like Letstango.com, jadopado.com, Aido.com etc). The question for online website was an open-ended questionnaire. The secondary data included a literature review from the main academic research portals which includes an analysis of the various theories of consumer behaviour, legal acts, models of online adoption. The research data and questionnaire were distributed among 1200 online shoppers in GCC countries from which 1133 internet users/ online shopper filled questionnaires who are classed as experienced and avid users. In final screening 972 questionnaires (properly filled) were finalized for data analysis. Their pattern of usage includes: A 38\% daily, 52\% regularly and $10 \%$ rarely. Of those surveyed, $79 \%$ have already purchased online. Based on the sample evidence, 5 of 7 risk women faced a greater risk than men in the form of online harassment. 35\% of those interviewed have suffered some kind of harassment while internet chatting. For each risk criterion, women have a perception of risk far greater than men for all risks, except the security risk where there is no difference between the sexes. In all the risk factors considered, age was also an important distinguishing factor, so at the age is higher than the perceived risk is strong. In a first phase, the questionnaire was tested with a dozen people. This pretest allowed us to change the wording of some questions or statements. Thereafter, 2 
modes of distributions have been made. First researcher used pilot testing for questionnaire validation and then distributed questionnaire among responded. 972 respondents filled the questionnaire, so the response rate was 94\%. Researcher utilized two means of sources for present research validation. First researcher used secondary data in which theories and literature were used to support the results then researcher utilized survey method in which questionnaire data was collected from customers.

The method is optional for original research articles. This method is written in descriptive and should provide a statement regarding the methodology of the research. This method as much as possible to give an idea to the reader through the methods used. This Method is optional, only for original research articles. It is not necessary to add methodology in General Review type of paper.

\section{Results and Discussion}

\section{Literature Review}

\section{E-Commerce Legal Regulations}

A number of federal, state, and international laws now govern e-commerce, which can involve complex contract and tax issues, security, and privacy issues. Because technology changes quickly, the laws regulating it are new and developing. The Uniform Computer Information Transactions Act (UCITA) intends to bring uniformity and certainty to the laws that apply to information technology transactions, just as the Uniform Commercial Code does for the sale of goods (Nasir, 2004). Few ecommerce legislations of GCC countries are mentioned in appendix (A).

\section{Global and National Commerce Act (E-Sign Act)}

There are few Global and National Commerce Act followed by various countries. The E-SIGN Act defines "electronic signature" (sometimes called a digital signature) as "an electronic sound, symbol or process attached to or logically associated with a contract or other record and executed or adopted by a person with the intent to sign the record." Because of this broad definition, telephone keypad agreements, such as (press 1 to agree) may be legally enforced as electronic contracts under the Act. A contract may not be denied legal effect only because a digital signature was used to form it. The $\boldsymbol{E}$-SIGN Act, which regulates any transactions in interstate and foreign commerce, does not alter existing law, and if state or federal law covers a transaction, including the Uniform Commercial Code, those statutes still control (Peter \& Deveaux, 2000).

\section{Legal Action for Data Protection and Privacy Violations}

Privacy is one of the most complex legal issues facing e-commerce today. Many sites collect personal information about their users, including names, addresses, and credit card information. Consumers who have pursued legal action because of privacy violations have successfully used common law to obtain redress, including breach of contract, unjust enrichment, fraud, and trespass to chattels, or invoked state statutes 
prohibiting deceptive or unfair trade practices by businesses. Some state laws specifically protect particular classes of data, such as medical information. The Federal Trade Commission (FTC) has recommended legislation to regulate online profiling. The FTC has used its authority to sue corporations that do not comply with privacy policies posted on their websites (Barr \& David, 2000).

\section{Copyright and Trademark}

Many attempts have been made to address the issues related to copyrights on digital content. E-commerce has a tremendous impact on copyright and related issues, and the scope of copyrights is affecting how e-commerce evolves. It is essential that legal rules are set and applied appropriately to ensure that digital technology does not undermine the basic doctrine of copyright and related rights. From one perspective, the Internet has been described as (the world's biggest copy machine). Older technologies such as photocopying, recording and taping are bound by rules and regulations regarding quantity, content, quality and time constraints. In contrast, on the Internet one person can send millions of copies all over the world (Robert and Thomas, 2000).

\section{Theoretical Background}

The theory "Effort in Purchase" proposed by Laroche in 2004, it is suggested that the greater the effort of consumers in a particular purchase, the greater would be the perception of satisfaction with the purchase process (Laroche, 2004). Thus, the perception of the outcome of the bid would be shaped in accordance with the effort invested (Sobihah, 2015). This theory supports this study and explained that individuals tend to perceive a measure of satisfaction as a result of efforts expended on the search of an item. It is emphasized that the degree of involvement with the purchase has an influence on risk perceived by consumers and reduction strategies (Dholakia, 1997) leading to the perception of satisfaction with the purchase process. There are many studies conducted on consumer online purchase (McCole, 2010). One consumer purchasing a product in different situations or different products may have a greater or lesser perception of risks (Park, Bhatnagar \& Rao, 2010).

\section{Relationship Analysis}

\section{Legal Risk in Online Marketing Effect on Consumer Satisfaction to Purchase}

Evidence supporting the influence of risk on the behaviour of consumers who shop online has been highlighted by numerous authors in the field. The attitude of online buyers significantly and positively affects customer satisfaction and their online purchasing behaviour. Internet-based transactions, management of consumers' risk is very important. Sobihah in 2015 analysed the effect of uncertainty about the product (risk functional) and the shipping process (source of risk) on the adoption of trade (Sobihah, 2015). For its part, the empirical evidence obtained by Lim in 2003 observed that the guarantees of privacy positively affect the confidence in purchasing 
on the Web (Lim, 2003), and through its intended behaviour (Choi, Kim \& Kim, 2011). There are various types of risk which are defined respectively:

Legal and Financial Risk: Pires in 2004 states that legal and financial risk has been employed in studies that relates to the loss of economic capital by the consumer, or by purchase and / or use of the product or service purchased (Mercado \& Rajagopal. 2015). It is the risk that the product is not worth the cost (Schiffman; Kanuk, 1997), and a broader definition, the financial risk is at any risk related to loss of property and money (Solomon, 1998).

Risk of Performance and functional: Bateson and Hoffman in 2001 explain that, the concept that the product or service purchased may not correspond to the task for which it was purchased (Bateson \& Hoffman, 2001). The risk functional, or performance, is risk that the product does not have the expected performance. It can be mitigated through customer satisfaction (Sobihah, 2015).

\section{Risk Mitigation Strategies in Online Electronic Commerce}

There are various strategies which organization can use to minimize the risk of online electronic commerce (Lim, et al, 2016). These strategies are given below:

Online Networking: A strategy to reduce the risk perceived by the search for information can be minimized through online networking sites which lots of consumers subscribe to where information is shared on product reviews, (Kim, 2005). The benefit of this is that the network provides reviews of customers around the world, quickly and without cost online, (Kuo, Hu \& Yang, 2013).

Search for online reviewers and rating system: In a study conducted by Wu in 2004, the results indicate that major strategies for risk reduction strategies with regards to high product ratings of the purchase are: firstly, the group of reference (except for products of high perceived risk, which would, in this case, the image of mark), followed by retailer's reputation, the brand image and guarantees (Lim, et al, 2016).

\section{The Involvement of Consumer and the Propensity to Take Risk (as a Moderator)}

One of the aspects mentioned in the literature of consumer behaviour is the influence in purchasing decisions and the individual's involvement with the process, product, and brand (Solomon, 2002). The consumer's involvement is defined as the perceived relevance of an individual on an object based on their needs, values and interests (Ranaweera, 2016). Corroborating with this idea, Engel in 1995 comments that this involvement increases when the social pressure is perceived, i.e., the extent to which consumers feel they will be judged by an acquisition, involvement tends to be higher (Sobihah, 2015). The involvement can be seen as the motivation to process information in that, to where there is a connection between the perceived needs, goals or values of and knowledge of consumer product, the individual will be motivated to pay attention in information about this (Mou, Shin, Cohen. 2015). 


\section{Cross-Border Law Enforcement}

Cross-border law enforcement can be defined as imposing sanctions on a business in another state than the state in which the law enforcer is established.2 It is assumed that the sanction is imposed due to the infringement of the law of the state in which the law enforcer is established and that that law is different from the law in the state where the business is established. "This article contains a division between Traditional Law Enforcement (direct law enforcement) and Alternative Law Enforcement (indirect law enforcement). Traditional law enforcement is sanctions imposed on the primary offender (the business) through the Judiciary, whereas Alternative Law Enforcement comprises other sanctions, such as imposing joint liability on intermediaries (secondary offenders), employ technical measures or using market forces" (Singh, 2018).

\section{Figure 1: Theoretical framework}

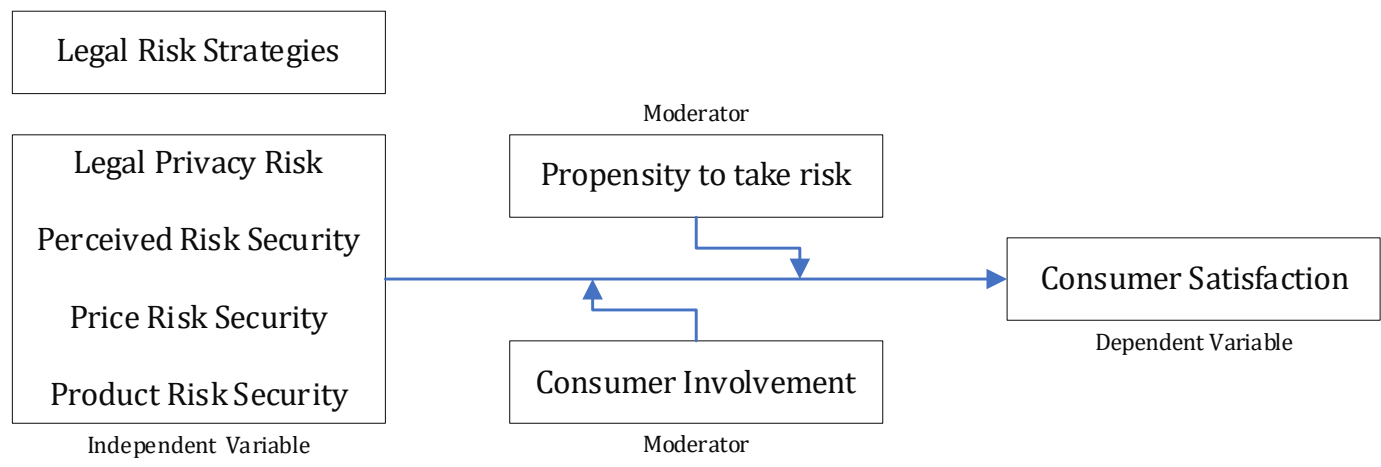

\section{Hypothesis Development}

H1: The legal risk reduction strategies have significant and positive impact on customer satisfaction in e-commerce

H1a: The Perceived Risk strategies have significant and positive impact on customer satisfaction in e-commerce

H1b: The Price Risk strategies have significant and positive impact on customer satisfaction in e-commerce

H1c: The Product Risk strategies have significant and positive impact on customer satisfaction in e-commerce

H1d: The Legal Privacy Risk strategies have significant and positive impact on customer satisfaction in e-commerce

H1e: The Time Risk strategies have significant and positive impact on customer satisfaction in e-commerce

H2: The involvement moderates the relationship between legal risk reduction strategies and customer satisfaction in e-commerce

H2a: The involvement moderates the relationship between Perceived Risk strategies and customer satisfaction in e-commerce 
H2b: The involvement moderates the relationship between Price Risk strategies and customer satisfaction in e-commerce

H2c: The involvement moderates the relationship between Product Risk strategies and customer satisfaction in e-commerce

H2d: The involvement moderates the relationship between Legal Privacy Risk strategies and customer satisfaction in e-commerce

H2e: The involvement moderates the relationship between Time Risk strategies and customer satisfaction in e-commerce

H3: The propensity to take risk moderate the relationship between legal risk reduction strategies and customer satisfaction in e-commerce

H3a: The propensity to take risk moderate the relationship between Perceived Risk strategies and customer satisfaction in e-commerce

H3b: The propensity to take risk moderate the relationship between Price Risk strategies and customer satisfaction in e-commerce

H3c: The propensity to take risk moderate the relationship between Product Risk strategies and customer satisfaction in e-commerce

H3d: The propensity to take risk moderate the relationship between Legal Privacy Risk strategies and customer satisfaction in e-commerce

H3e: The propensity to take risk moderate the relationship between Time Risk strategies and customer satisfaction in e-commerce

\section{Empirical Analysis}

\section{Validation and Robustness of Regression Model}

Validity of present study shows that findings truly represent the present study phenomena. Study finds out Eign value which is 0.566 and it is less than 1. (Eign value $<1$ ) shows that data is valid in nature. Percentage of variance should be less than $50 \%$ and present study percentage of variance is less than fifty. F statistics of at least 3.95 is needed to accept alternative hypothesis. Present study model F statistics value is 96.23 shows overall significance of regression model. Present study utilized model of risk management strategies and their impact on customer satisfaction is overall significant.

\section{The Correlation Analysis Variables}

Correlation and descriptive analysis are one of the important analysis techniques used to determine the association among independent and dependent variables and it also explains that how much one variable depends on other variable. In present study, correlation analysis shows that all variable correlation value lies within range $(\mathrm{CA}<0.80)$ so it is stated that all variable acts independently and can use for further analysis. 
Table 1. The Correlation Analysis Variables in Table

\begin{tabular}{|c|c|c|c|c|c|c|c|c|c|c|}
\hline Variables & $\mathbf{M}$ & SD & PerR & $\begin{array}{l}\text { PriR } \\
\end{array}$ & ProR & PrivR & TR & PTR & CI & $\mathrm{CS}$ \\
\hline $\begin{array}{l}\text { Perceived Risk } \\
\text { Security }\end{array}$ & 1.946 & 0.667 & 1 & & & & & & & \\
\hline Price Risk Security & 2.157 & 0.786 & $0.687^{*}$ & 1 & & & & & & \\
\hline $\begin{array}{l}\text { Product Risk } \\
\text { Security }\end{array}$ & 1.916 & 0.634 & $0.711^{*}$ & $0.636^{*}$ & 1 & & & & & \\
\hline Legal Privacy Risk & 2.017 & 0.670 & $0.698^{*}$ & $0.654^{*}$ & $0.759^{*}$ & 1 & & & & \\
\hline Time Risk Security & 2.199 & 0.946 & $0.493^{*}$ & $0.406^{*}$ & $0.536^{*}$ & $0.477^{*}$ & 1 & & & \\
\hline $\begin{array}{l}\text { Propensity to take } \\
\text { Risk }\end{array}$ & 1.846 & 0.567 & $0.741^{*}$ & $0.627^{*}$ & $0.722^{*}$ & $0.556^{*}$ & $0.759^{*}$ & 1 & & \\
\hline $\begin{array}{l}\text { Customer } \\
\text { Involvement }\end{array}$ & 2.167 & 0.886 & $0.721^{*}$ & $0.788^{*}$ & $0.536^{*}$ & $0.453^{*}$ & $0.666^{*}$ & $0.677^{*}$ & 1 & \\
\hline $\begin{array}{l}\text { Customer } \\
\text { Satisfaction }\end{array}$ & 2.116 & 0.544 & $0.546^{*}$ & $0.646^{*}$ & $0.697^{*}$ & $0.755^{*}$ & $0.456^{*}$ & $0.731^{*}$ & $0.435^{*}$ & 1 \\
\hline
\end{tabular}

\section{Regression Analysis}

After determining relationship between variables through correlation, regression analysis is used to assess the cause-and-effect relationship between dependent and independent variable. It determines that how much change in dependent variable is caused by independent variables. Below mention regression model equations which are used by researcher for present study:

First: Equation for Customer Involvement Interaction Term

Customer Satisfaction $=\alpha+\beta_{1}$ (Perceived Risk Security) $+\beta_{2}$ (Customer Involvement) $+\beta_{3}$ (Interaction PerR_CI) $+e$

Customer Satisfaction $=\alpha+\beta_{1}$ (Price Risk Security) $+\beta_{2}$ (Customer Involvement $)+\beta_{3}$ (Interaction PerR_CI) $+e$

Customer Satisfaction $=\alpha+\beta_{1}$ (Product Risk Security) $+\beta_{2}$ (Customer Involvement) $+\beta_{3}$ (Interaction ProR_CI) $+e$

Customer Satisfaction $=\alpha+\beta_{1}$ (Legal Privacy Risk) $+\beta_{2}$ (Customer Involvement $)+\beta_{3}$ (Interaction PrivR_CI) $+e$

Customer Satisfaction $=\alpha+\beta_{1}$ (Time Risk Security $)+\beta_{2}$ (Customer Involvement $)+\beta_{3}$ (Interaction TR_CI) $+e$

\section{Second. Equation for Propensity to Take Risk Interaction Term}

Customer Satisfaction $=\alpha+\beta_{1}$ (Perceived Risk Security) $+\beta_{2}$ (Propensity to take Risk) $+\beta_{3}$ (Interaction PerR_PTR) $+e$

Customer Satisfaction $=\alpha+\beta_{1}$ (Price Risk Security) $+\beta_{2}$ (Propensity to take Risk $)+\beta_{3}$ (Interaction PerR_PTR) $+e$ 
Customer Satisfaction $=\alpha+\beta_{1}$ (Product Risk Security) $+\beta_{2}$ (Propensity to take Risk)

$+\beta_{3}$ (Interaction ProR_PTR) $+e$

Customer Satisfaction $=\alpha+\beta_{1}$ (Legal Privacy Risk) $+\beta_{2}$ (Propensity to take Risk $)+\beta_{3}$ (Interaction PrivR_PTR) $+e$

Customer Satisfaction $=\alpha+\beta_{1}$ (Time Risk Security) $+\beta_{2}$ (Propensity to take Risk) $+\beta_{3}$ (Interaction TR_PTR) $+e$

In this equation, ' $\mathrm{e}$ ' is the error term that measures influence of variables other than independent variables.

Study shows that beta value of all variables shows strong relationship between risk strategies and customer satisfaction and also shows the moderators impact on present relationship. Results of present study explains that all relationships are significant in nature as all variables $\mathrm{z}$ score $\mathrm{P}$ values are less than 0.05 which shows that hypothesis $\mathrm{H} 1 \mathrm{a}, \mathrm{H} 1 \mathrm{~b}, \mathrm{H} 1 \mathrm{c}, \mathrm{H} 1 \mathrm{~d}$ and $\mathrm{H} 1 \mathrm{e}$ are accepted and perceived price, products, privacy and time risk securities have significant impact on customer satisfaction. Interaction terms of customer involvement and Propensity to take Risk are also significant which shows that hypothesis $\mathrm{H} 2$ and $\mathrm{H} 3$ all dimensions are accepted. Customer involvement and Propensity to take Risk significantly influence the relationship between risk strategies and customer satisfaction.

Table 2. Regression Analysis

\begin{tabular}{llllll}
\hline & $\begin{array}{l}\text { Un-standardized } \\
\text { Coefficient }\end{array}$ & $\begin{array}{l}\text { Standardized } \\
\text { Coefficient }\end{array}$ & & & \\
\hline Variables & Beta & Beta & T & Sig & VIF \\
\hline Constant & 0.002 & & 0.036 & 0.024 & \\
Z score (PerR) & 0.225 & 0.225 & 2.662 & 0.009 & 3.048 \\
Z score (PriR) & 0.192 & 0.192 & 2.736 & 0.007 & 2.096 \\
Z score (ProR) & 0.457 & 0.457 & 5.150 & 0.000 & 3.352 \\
Z score (PrivR) & 0.049 & 0.049 & 2.333 & 0.000 & 1.721 \\
Z score (TR) & 0.236 & 0.236 & 2.556 & 0.003 & 2.096 \\
Z score (CI) & 0.224 & 0.224 & 4.323 & 0.000 & 3.352 \\
Z score (PTR) & 0.344 & 0.344 & 0.772 & 0.000 & 1.721 \\
InteractionPerR_CI & 0.051 & 0.063 & 0.698 & 0.000 & 3.497 \\
InteractionPri_CI & 0.080 & 0.087 & 1.109 & 0.000 & 2.593 \\
InteractionPro_CI & 0.017 & 0.025 & 0.298 & 0.001 & 2.994 \\
InteractionPriv_CI & 0.246 & 0.226 & 5.150 & 0.000 & 2.096 \\
InteractionTR_CI & 0.254 & 0.244 & 2.333 & 0.003 & 3.352 \\
InteractionPer_PTR & 0.090 & 0.087 & 2.556 & 0.000 & 1.721 \\
InteractionPri_PTR & 0.017 & 0.025 & 4.323 & 0.000 & 2.096 \\
InteractionPro_PTR & 0.226 & 0.226 & 0.772 & 0.002 & 3.352 \\
InteractionPriv_PTR & 0.070 & 0.087 & 0.698 & 0.003 & 1.721 \\
InteractionTR_PTR & 0.087 & 0.085 & 1.109 & 0.000 & 3.497 \\
\hline
\end{tabular}


Table 3. Summary of Result

\begin{tabular}{|c|c|c|c|}
\hline Hypotheses & Results & P-value & $\begin{array}{l}\text { Reason of } \\
\text { rejection }\end{array}$ \\
\hline $\begin{array}{l}\text { H1a: The Perceived Risk strategies have } \\
\text { significant and positive impact on } \\
\text { customer satisfaction in e-commerce }\end{array}$ & Accepted & 0.009 & Significant \\
\hline $\begin{array}{l}\text { H1b: The Price Risk strategies have } \\
\text { significant and positive impact on } \\
\text { customer satisfaction in e-commerce }\end{array}$ & Accepted & 0.007 & Significant \\
\hline $\begin{array}{l}\text { H1c: The Product Risk strategies have } \\
\text { significant and positive impact on } \\
\text { customer satisfaction in e-commerce }\end{array}$ & Accepted & 0.000 & Significant \\
\hline $\begin{array}{l}\text { H1d: The Privacy Risk strategies have } \\
\text { significant and positive impact on } \\
\text { customer satisfaction in e-commerce }\end{array}$ & Accepted & 0.000 & Significant \\
\hline $\begin{array}{l}\text { H1e: The Time Risk strategies have } \\
\text { significant and positive impact on } \\
\text { customer satisfaction in e-commerce }\end{array}$ & Accepted & 0.003 & Significant \\
\hline $\begin{array}{l}\text { H2a: The involvement moderates the } \\
\text { relationship between Perceived Risk }\end{array}$ & Accepted & 0.000 & Significant \\
\hline $\begin{array}{l}\text { strategies and customer satisfaction in e- } \\
\text { commerce }\end{array}$ & Accepted & 0.000 & Significant \\
\hline $\begin{array}{l}\text { H2b: The involvement moderates the } \\
\text { relationship between Price Risk } \\
\text { strategies and customer satisfaction in e- } \\
\text { commerce }\end{array}$ & & & \\
\hline $\begin{array}{l}\text { H2c: The involvement moderates the } \\
\text { relationship between Product Risk } \\
\text { strategies and customer satisfaction in e- } \\
\text { commerce }\end{array}$ & Accepted & 0.001 & Significant \\
\hline $\begin{array}{l}\text { H2d: The involvement moderates the } \\
\text { relationship between Privacy Risk } \\
\text { strategies and customer satisfaction in e- } \\
\text { commerce }\end{array}$ & Accepted & 0.000 & Significant \\
\hline $\begin{array}{l}\text { H2e: The involvement moderates the } \\
\text { relationship between Time Risk } \\
\text { strategies and customer satisfaction in e- } \\
\text { commerce }\end{array}$ & Accepted & 0.003 & Significant \\
\hline $\begin{array}{l}\text { H3a: The propensity to take risk } \\
\text { moderate the relationship between }\end{array}$ & Accepted & 0.000 & Significant \\
\hline $\begin{array}{l}\text { Perceived Risk strategies and customer } \\
\text { satisfaction in e-commerce }\end{array}$ & & & \\
\hline $\begin{array}{l}\text { H3b: The propensity to take risk } \\
\text { moderate the relationship between Price } \\
\text { Risk strategies and customer satisfaction } \\
\text { in e-commerce }\end{array}$ & Accepted & 0.000 & Significant \\
\hline $\begin{array}{l}\text { H3c: The propensity to take risk } \\
\text { moderate the relationship between }\end{array}$ & Accepted & 0.002 & Significant \\
\hline
\end{tabular}


Product Risk strategies and customer satisfaction in e-commerce

H3d: The propensity to take risk Accepted 0.003 Significant moderate the relationship between Privacy Risk strategies and customer satisfaction in e-commerce

H3e: The propensity to take risk Accepted 0.000 Significant moderate the relationship between Time Risk strategies and customer satisfaction in e-commerce

\section{Conclusion}

Theories exist to discuss the theory of perceived risk, but no theory deals with questions of change in the perceived risk while using the Internet. The development of assumptions of this studies questionnaire, tours around five risks dimensions in electronic commerce. These dimensions were indicative of a change in Internet user's perceptions. Thus, we realized that what the characteristics of legal risk influence on customer purchase perception are. Customer satisfaction is one of the major factors studied by current research. This study is supported with various Global and National Commerce Act (E-SIGN Act), Legal action for data protection and privacy violations act, E-Commerce CAN-SPAM Act of 2003 and Copyright \& Trademark Act. The study represents different legal risk strategies which organizations should understand and provide security to their customers so that they get more involved with online services and encourage propensity to take risk which leads toward customer satisfaction and their repeat purchases. In each risk situation reveals that the purchase of a book is significantly higher than buying a laptop. This would mean that if transaction amount is lesser it is less risky for customer and they don't want to share their credit card number and their personal information online. This is because of risk which customer perceived during their online transactions. Indeed, in 2004, risks related to learning (lost time) and consumption patterns (product risk and intimacy) are based on customer satisfaction. If customer is satisfied with his internet transactions, he becomes risk taker. Present study examined the impact of legal risktaking strategies which involved perceived, product, price, legal privacy and time risk security and investigated these strategies influence on customer satisfaction. Study explained that these strategies (confidentiality, time security, no visual distortion of product) taken by organization have major influence on customer satisfaction and this relationship is influenced by customer involvement and their propensity to take risk variables. Data was collected from internet users/online shoppers from GCC countries customers. 972 respondents filled the questionnaire, so the response rate was $94 \%$. Researcher utilized two means of sources for present research validation. First researcher used secondary data in which theories and literature were used to support the results then researcher utilized survey method in which questionnaire data was collected from customers. Many sites provide clear information on safety, but more than half do not provide this information clearly and in a way that is sufficiently accessible. It is therefore imperative for merchants and retailers on the 
web to review the usability of their sites to put forward safety tools that would be visible to all users such as signs and labels and certifications. It is important for the organizations to build their security systems and provide them good experience and less risky online environment so that more they get involved with product more they will be satisfied and repurchase product. Future study should include more risk dimensions in study and also should increase study sample which will be helpful to increase the generalizability of study.

According to study results, legal risk is very important in GCC countries which ultimately influence the customer involvement, satisfaction and purchasing behavior. GCC countries should attempts to create a coherent legal and regulatory framework (like Lessons can be learnt from the EU). It will help to reduce the legal risk and remove the obstacles to the growth of e-commerce in GCC countries by affirming a certain level of transparency by imposing prior information requirements for electronic contracts, as well as regulating commercial communication and advertisements and regulating consumers' technical errors. This system will also help to regulate the liabilities of intermediary service providers, as well as the right of withdrawal rules. Furthermore, GCC countries should create an efficient system of ODR that would help to build trust in online transactions and preserve online business relationships in the long term.

\section{References}

Ariff M.S.M, Sylvester M, Zakuan N, Ismail K and Ali, K.M, (2014), Consumer Perceived Risk, Attitude and Online Shopping Behaviour; Empirical Evidence from Malaysia, IOP Conference Series: Materials Science And Engineering

Barr, David D. (2000), "The Need of a Broad Standard in Global E-Commerce" The Internet Law Journal, Dec. 26,

Bateson John E. G. And Hoffman, K. Douglas. (2001) Marketing Service: Bookman.

Bianchi \& Mathews. (2016). Internet Marketing and Export Market Growth In Chile. Journal of Business Research 69, 426-434.

Bond, Robert, "International Legal Issues of E-Commerce" Legal Updates, http://www.faegre.com, 2003.

Choi, H., Kim, Y. And Kim, J. (2011), "Driving Factors of Post Adoption Behavior in Mobile Data Services", Journal of Business Research, Vol. 64 No. 11, Pp. 12127.

Cunningham, L.F., Gerlach, J.H., Harper, M.D., Young, C.E. (2005), “Perceived Risk and The Consumer Buying Process: Internet Airline Reservations", International Journal of Service Industry Management, Vol. 16 No.4, Pp.357-72.

Dholakia, Utpal M. (1997) An Investigation of The Relationship Between Perceived Risk and Product Involvement. Advances in Consumer Research, V. 24, P.159167.

Engel, James F.; Blackwell, Roger D. and Miniard, Paul W. (1995) Consumer Behaviour. 8. Ed. Orlando: The Dryden Press. 951 P. Bibliography: P. 441 - 442. 
Gierl, H., Hammer, C. (2003), "Fear of Loss of Anonymity on the Internet and Consumers' Reactions: An Empirical Investigation", Yearbook Of Marketing and Consumer Research, Vol. 1 Pp.89-106.

Kim, E., Hong, T., (2010). Segmentating Customers in Online Stores from Factors that Affect the Customer's Intention to Purchase., Pp. 383-388

Kim, L.H., Kim, D.J., Leong, J.K. (2005), "The Effect of Perceived Risk on Purchase Intention in Purchasing Airline Tickets Online", Journal of Hospitality \& Leisure Marketing, Vol. 13 No.2, Pp.33-53.

Klein, H. E Sterk, E.C. (2003) "At Risk” Women Who Think That They Have No Chance of Getting Hiv: Self-Assessed Perceived Risks. Woman and Health, V.38, N.2, P.47-63

Kovacs .M, Farias. H. (2002). Perceived Risks and Ways to Purchase: The Duality Versus Internet Consumers Online. Journal of Economics and Management, V.1, N.2, April / June

Kuo Y F, Hu T L., \& Yang, S. C. (2013) Effects of Inertia and Satisfaction in Female Online Shoppers On Repeat-Purchase Intention. Managing Service Quality: An International Journal.168 - 187

Laroche, M., Bergeron, J. And Goutaland, C. (2004) How Intangibility Affects Perceived Risk: The Moderating Role of Knowledge and Involvement. The Journal of Services Marketing, V.17, N.2 / 3, P.122-141.

Lim, N. (2003), “Consumer Perceived Risk: Sources Versus Consequences”, Electronic Consumer Research and Applications, Vol. 2 Pp.216-28.

Lim.Y. J, Osman A, Salahuddin' S.N, Romle A. R, Abdullah. S, (2016), Factors Influencing Online Shopping Behavior: The Mediating Role of Purchase Intention, Procedia Economics and Finance, Vol 32, 401- 410

Mccole, P., Ramsey, E. And Williams, J. (2010), “Trust Considerations on Attitudes Towards Online Purchasing: The Moderating Effect of Privacy and Security Concerns", Journal of Business Research, Vol. 63 Nos 9/10, Pp. 1018-24.

Mercado \& Rajagopal. (2015). Driving Consumers Toward Online Retailing Technology: Analyzing Myths and Realities. Journal of Transnational Management 20, 155-171.

Mitchell, V.-W. (1998) A Role for Consumer Risk Perceptions in Grocery Retailing. British Food Journal, N.4, P.171-183.

Mitchell, V.-W. And Greatorex, M. (1990) Consumer Purchasing in Foreign Countries: The Perceived Risk Perspective. International Journal of Advertising, V.9, N.4, P.295-307.

Mou, Shin \& Cohen. (2015). Trust and Risk in Consumer Acceptance Of E-Services. Electronic Commerce Research.

Nasir, M. A, (2004), LEGAL ISSUES INVOLVED IN E-COMMERCE, Journal of Ubiquity, Volume 4, Issue 49

Oliver, Richard L. Satisfaction: (1997) A Behavioural Perspective on The Consumer. New York: Mcgraw-Hill Company. 
Park, I., Bhatnagar, A. And Rao, H.R. (2010), "Assurance Seals, On-Line Customer Satisfaction, And Repurchase Intention", International Journal of Electronic Commerce, Vol. 14 No. 3, Pp. 11-34.

Peter,S and Deveaux, S, (2000), "Jurisdiction in Cyberspace" IDG News Service, see also http://www.pcwo

Ranaweera. (2016). Perspective of Trust Towards E-Government Initiatives in Sri Lanka. Springerplus 5.

Robert, C and Thomas, U, (2000), Law \& Economics, 3rd edition, AddisonWesley, pp. 336.

Santos, J. (2002), “From Intangibility to Tangibility on Service Quality Perceptions: A Comparison Study Between Consumers and Service Providers in Four Service Industries", Managing Service Quality, Vol. 12 No.5, Pp.292-302.

Schhiffman J.B and Kanuk. L. L (1997) Consumer Behavior Published by Prentice Hall Sixth Edition .446

Singh, A. (2018). E-Commerce interfering with Privacy: Perceived Risks and Security issues with Techno-policy outcomes. In Digital Transformation Strategies and trends in E-learning: Privacy, Preservation and Policy (1st ed., pp. 802-823).

Sobihah M, Mohamad M, Ali N. A. M, Ismail W. Z. W (2015), E-Commerce Service Quality on Customer Satisfaction, Belief and Loyalty: A Proposal, Mediterranean Journal of Social Sciences, Vol 2

Solomon (2002) The Consumer Behaviour: Buying, Having Being. 5 Ed. Porto Alegre: Bookman, P.446. Bibliography: P.216-217

Solomon, Michael R. (1998) Consumer Behaviour: Buying, Having and Being. 4. Ed. New Jersey: Prentice Hall. 640 P: P.280-281

Son, M. And Han, K. (2011), "Beyond the Technology Adoption: Technology Readiness Effects on Post-Adoption Behavior", Journal of Business Research, Vol. 64 No. 11, Pp. 1178-82.

Wu, George, Jiao. Z, And Richard. G, (2004), “Decision Under Risk," In Blackwell Handbook of Judgment and Decision Making, Nigel Harvey And Derek Koehler, Eds. London: Blackwell Publishing, Forthcoming.

Zeithaml, V.A., Bitner, M.J. (2003), Services Marketing: Integrating Customer Focus Across the Firm, 3rd Ed., Mcgraw-Hill, New York, Ny. 